\title{
袖壁付き柱の曲げ終局強度に関する考察 \\ AN INVESTIGATION ON FLEXURE STRENGTH OF COLUMNS WITH WING WALLS
}

\author{
大宮 幸*, 林 静 雄** \\ Miyuki OHMIYA and Shizuo HAYASHI
}

\begin{abstract}
In this paper, the authors investigate the influence of the wing walls on the flexure strength of the columns by the sectional analysis. The results are as follows;

1) The analytical results showed that the relationship between the moment and the axial force of the columns with wing walls is different from that of the rectangular cross'section.

2) The flexure strength calculated by the existing conventional equations for columns with wing walls dose not accord with the analytical value of that.

3) The authors present the new flexure strength formula. The calculated value by that has good accordance with the test and analytical value.
\end{abstract}

Keywords: Columns with Wing Walls, Sectional Analysis, Flexure Strength 袖壁付き柱, 曲げ解析, 曲げ終局強度

\section{1.はじめに}

現在, 鉄筋コンクリート造建物において, 袖壁, 腰壁, 垂れ壁な どの 2 次壁は, スリットなどにより構造部材から絶縁され, 周辺部 材及び建物の耐震性能に影響を及ぼさないように設計されている。 これは, 建物に明確な崩壊形を形成し, 勒性に富む建物にする “積 極的な”目的のほかに，2 次壁のモデル化が不明確であるため耐震 要素として設計に取り入れることができず，絶縁せざるを得ないと いう“消極的な”目的がある。

先の阪神大震災では, スリットに関して, 完全スリットはその有 効性が証明されたものの，以下のような問題が指摘された：(1)部 分スリットや不適切なスリットによる構造被害が報告され，2次壁 を完全に非構造壁にすることは難しいことがわかった。（2) 2 次壁 を非構造化したことにより骨組の変形が過大となり，ほとんどの梁 端が補修不可能なほど変形し, 修復が困難となったケースがあった。

(3)防音・防水などの面から十分なスリット間隔が確保できず， 2 次壁の破壊が骨組より先行し, 隣接する屝・空の開閉を困難にし避 難の妨げとなった。十分なスリット間隔を設けることは, 施工性, 経済性の他に, 防音・防水といった壁の基本性能確保の面で大きな 問題となっている。

これら 2 次壁のうち袖壁は，柱とともにせん断力，変動軸力を負 担し, 柱の剛性, 耐力を上昇させ, 変形を抑える性質がある。学校校 舎, マンションなど, 比較的一様に袖壁が存在する建物では, 構造計 算外の余力として存在した袖壁により建物倒壊を免れた例も過去の 震災において多く見られ，袖壁が周辺部材に及ぼす影響を適切に把 握できるならば，過大な変形を防ぎ高いエネルギ一吸収能を持つ建
物を計画できる。また袖壁のモデル化が不明確であるという理由か ら、設けざるを得なかったスリットを省くことにより, 施工性, 経済 性，壁としての基本性能を満たすことができる。

一方, 袖壁が周辺部材に与える影響を明らかにすることは, 耐震 診断, 耐震補修を適切に行う上でも重要なことである。しかしなが ら現在, 袖壁付き柱のモデル化に関して, 力学性状に基づいた明確 な基準は存在しない。日本建築防災協会による既存鉄筋コンクリー 卜建築物の耐震診断基淮 1 ) には, 袖壁付き柱をその袖壁形状によ り, 柱, 袖壁付き柱, 片側柱付き壁にモデル化するとしているが, この基準は袖壁長さと階高の比による単一的な基準であり, 袖壁長 さ，厚さといった様々な要因に対して詳細に検討されたものではな い。そのため, 最終的なモデル化の判断は, 診断者の判断に任され ているのが現状である。しかし, 壁, 袖壁付き柱といったなんらか の部材にモデル化されたとしても, 袖壁付き柱の終局強度式の信頼 性は柱・梁にくらべて信頼性が低いとされ2)，また袖壁付き柱に対 し壁の終局強度式を適用するにも, その適合性や適用範囲は検討さ れておらず，適切に袖壁付き柱の耐震性能を評価できるかという点 においては，疑問が残る。

以上の点から, 構造設計, 耐震診断によらず, 袖壁付き柱の力学 性状を明らかにする必要がある。そのため, 本論文では, まず袖壁 付き柱の曲げ終局強度に着目し, 袖壁長さ, 厚さといった要因が袖 壁付き柱の曲げ終局強度に与える影響を, e 関数法を用いた曲げ解 析から明らかにした。次に現行の袖壁付き柱, 柱, 壁の曲げ終局強 度式と解析結果を比較することにより，これら曲げ終局強度式では 袖壁付き柱の曲げ終局強度を適切に評価できないことを示した。最

\footnotetext{
注）本研究の一部は，既に文献9)，10)において発表している。

* 東京工業大学大学院総合理工学研究科環境理工学創造專攻 大学院生・修士 (工学)

** 東京工業大学建築物理研究センター 教授・工博
}

Graduate Student, Dept. of Environmental Science and Technology, Graduate School of Science and Engineering, Tokyo Institute of Technology, M. Eng. Prof., Structural Engineering Research Center, Tokyo Institute of Technology, Dr. Eng. 
後に, 解析結果を基に, 柱と連続的にかつ簡易な形で袖壁付き柱の 曲げ終局強度式を評価できる曲げ終局強度式を提案した。

\section{2. 解析概要}

\section{2-1. 解析試験体}

壁長さ, 壁厚さが袖壁付き柱の曲げ終局強度に及ぼす影響を調べ るため, e 関数法による曲げ解析を行った。解析試験体は，文献 3 ) を 参考に, 既存の学校校舎の桁行方向中柱を想定して計画した。図一 1 に示すとおり, 柱幅に対し $\alpha$ 倍の厚さと, 柱せいに対し $\beta$ 倍の長 さをもつ壁が，柱の両側及び片側に付加した場合を考える。表- 1 に変動要因一覧を示す。 $\alpha$ は, 2 次壁と耐震壁程度の壁厚を想定し て，それぞれ $0.24,0.40$ の 2 種類， $\beta$ は $0.5,1.0,1.5,2.0$ の 4 種類であ る。各試験体とも柱断面形状, 柱主筋比, 壁繸筋比は等しく, 柱 500 $\times 550(\mathrm{~mm})$ ，柱主筋 14-D22（主筋比 1.97\%）壁筋 $9 \phi$-@200（壁筋 比 $0.27 \%(\alpha=0.24), 0.16 \%(\alpha=0.40))$ である。なお，材料強度は 参考とした学校校舎のものを使用した。

\section{2-2. 解析仮定}

断面の歪は平面を保持すると仮定する。コンクリートの応力度 歪関倸は，圧縮域は $\mathrm{e}$ 関数法により表現し，引張域は，引張強度ま では弾性とし，引張強度に相当する歪度を超える歪度では，コンク リートの応力度を需とする。鉄筋の応力度 - 歪関係は，降伏点強度 までは弾性とし、降伏点強度に相当する歪度を超える歪度では，鉄 筋の応力度は降伏点強度に等しいものとする。また、本研究では原 則として建物内に連層で存在する袖壁を対象としているので，軸力 は全断面の塑性重心位㯰に作用するものとする。

\section{3. 解析結果}

図- 2 に, 両側及び片側袖壁付き柱の曲げ終局強度時の曲げモ一 メントー軸力 $(M-N)$ 相関曲線を示す。曲げ終局強度は，解析で得ら れた最大抵抗モーメントと定義した。図－2 の横軸は曲げモーメント $\mathrm{M}$ を $\mathrm{BD}^{2} \mathrm{~F}_{\mathrm{c}}$ 除した值（以下モーメント係数と記す），綎軸は軸力 $\mathrm{N}$ を $\Sigma$ $\mathrm{AFc}$ （ $\Sigma \mathrm{A}$ : 袖壁も含めた全断面積 $=\left(1+\alpha\left(\beta_{\mathrm{c}}+\beta_{\mathrm{t}}\right) \mathrm{BD}\right)$ て除 した值（以下軸力比と記す）となっている。なお図中の点線は柱の みの $\mathrm{M}-\mathrm{N}$ 相関曲線である。

袖壁の取り付き方によってM-N 相関曲線に明確な違いが現れてい る。両側壁付き柱の $\mathrm{M}-\mathrm{N}$ 相関曲線（図－2，(1)，(2)）は， $\alpha ， \beta$ によ らず軸力比が 0.5 付近で曲げモーメントが最大となる。これに対し 圧縮側片側袖壁付き柱（図-2, (3)，(4)）の $\mathrm{M}-\mathrm{N}$ 相関曲線は，低軸力 で曲げモーメントは最大となり，反対に引張側片側袖壁付き柱の場 合は高軸力で最大となっている。この傾向は， $\alpha ， \beta$ が大きいほど 顕著である。これは，圧縮側に袖壁がつく場合，柱主筋の引張力に つりあうためのコンクリート断面幅（＝壁厚）が狭いため，終局時に 柱の引張主筋が降伏する軸力（つりあい軸力）が低くなるためであ り，また引張側に袖壁がつく場合は，引張側に壁筋が存在し，かつ 圧縮力を受けるコンクリート断面幅（=柱幅）が広いため，つりあ い軸力が高くなるためである。

図一 2 によると，両側袖壁付き柱は片側袖壁付き柱に比へ，比較 的柱と似た $\mathrm{M}-\mathrm{N}$ 相関曲線を描く。そこで，両側袖壁付き柱と，これ と等しい断面積とせいを持つ長方形断面（以下等価長方形断面と記 す）の $\mathrm{M}-\mathrm{N}$ 相関曲線とを比較することにより，袖壁付き柱のような 異形断面と長方形断面の $\mathrm{M}-\mathrm{N}$ 相関曲線の違いを検討した。図- 3 は, $\alpha=0.24, \beta=2.0$ の両側袖壁付き柱と，これと等しい断面積とせい を持つ等価長方形断面（柱主筋，壁縌筋位置は袖壁付き柱と同じ）

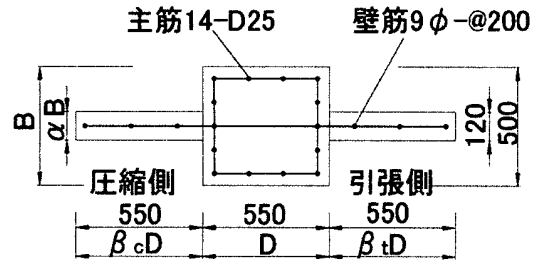

(単位 : mm)

$\mathrm{B}:$ 柱幅, $\mathrm{D}$ : 柱せい, $\alpha$ : 壁厚比 $(=\mathrm{t} / \mathrm{B}, \mathrm{t}$ : 壁厚 $), \beta$ : 張 出比 $(=1 / \mathrm{D}, 1$ : 壁長さ, $\beta \mathrm{c}, \beta \mathrm{t}$ はそれぞれ圧縮側張出比 引張側張出比)

図- 1 解析試験体

表 -1 試験体概要

\begin{tabular}{|c|c|}
\hline \multicolumn{2}{|c|}{ 変動要因 } \\
\hline 壁厚比 & $0.24 、 0.40$ の2種類 \\
\hline 張出比 & $0.5 、 1.0 、 1.5,2.0$ の4種類 \\
\hline 壁の取り付き方 & 両側、片側 (圧縮側·引張側) \\
\hline \multicolumn{2}{|c|}{ 共通要因 } \\
\hline
\end{tabular}

柱断面 : $500 \mathrm{~mm} \times 550 \mathrm{~mm}$ 、柱主筋 : 14-25D（主筋比 1.97 $\%$ ，降伏強度 $343 \mathrm{kN} / \mathrm{mm}^{2}$ ，壁縦筋 $9 \phi$ - @ $200 \mathrm{~mm}$ (壁筋 比 $0.27 \%(\alpha=0.24), 0.16 \%(\alpha=0.40)$, 降伏強度 $\left.294 \mathrm{kN} / \mathrm{mm}^{2}\right)$ ，コンクリート強度 $20.6 \mathrm{kN} / \mathrm{mm}^{2}$

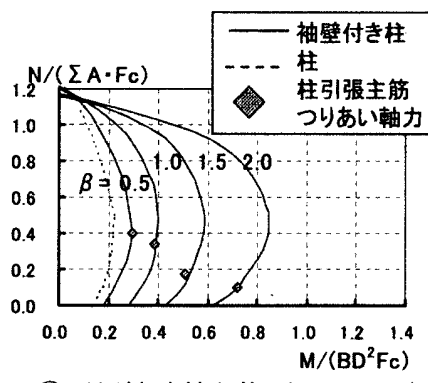

(1)両側袖壁付き柱 $(\alpha=0.24)$

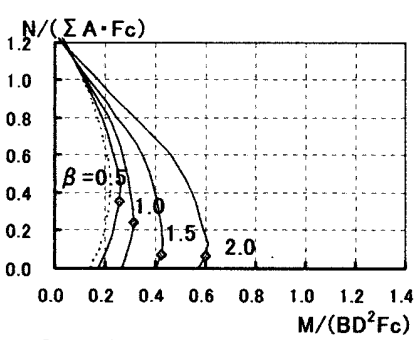

(3)圧縮側片側袖壁付き柱 $(\alpha=0.24)$

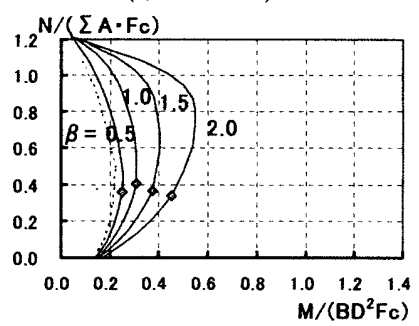

(5)引張側片側袖壁付き柱 ( $\alpha=0.24)$

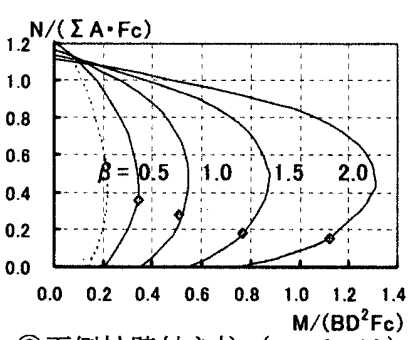

(2)両側袖壁付き柱 $(\alpha=0.40)$

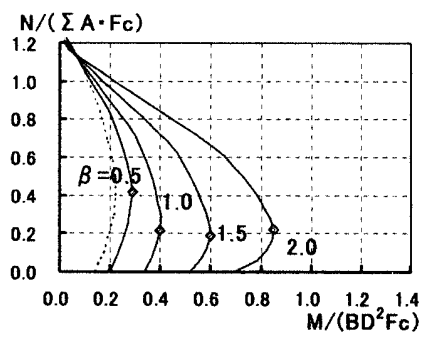

(4)圧縮側片側袖壁付き柱 $(\alpha=0.40)$

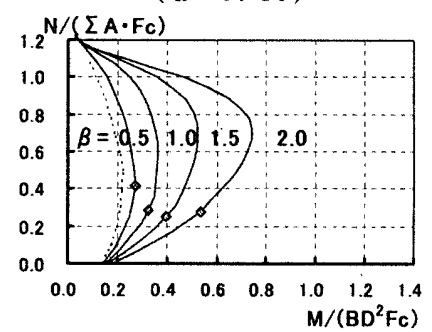

(6)引張側片側袖壁付き柱 $(\alpha=0.40)$
図一 2 袖壁付き柱の曲げモーメントー軸力相関曲線

について, 図-3の a ではM-N 相関曲線の比較を, 図 -3 の $\mathrm{b}$ では軸力 比とコンクリート圧縮合力作用位置 X c の関係を比較したものであ る。図-3，aより，同じ軸力比であっても，袖壁付き柱のモーメン 卜は，等価長方形断面よりも低くなることがわかる。また，図-3. b より, 同じ軸力比であっても, 袖壁付き柱のコンクリート圧縮合 
力作用位置は，等価長方形断面よりも柱寄りとなることがわかる。 これは, 袖壁付き柱の場合, 圧縮縁のコンクリート断面幅（=壁厚） が狭く, 中央部の断面幅 (=柱幅) が広いため, コンクリート圧縮 合力作用位置が柱寄りになるためである。このため袖壁付き柱の曲 げモーメントは等価長方形断面よりも低くなる。柱幅と壁厚が異な るために, 袖壁付き柱の $\mathrm{M}-\mathrm{N}$ 相関曲線は等価長方形断面とは異 なった挙動を示すことがわかる。
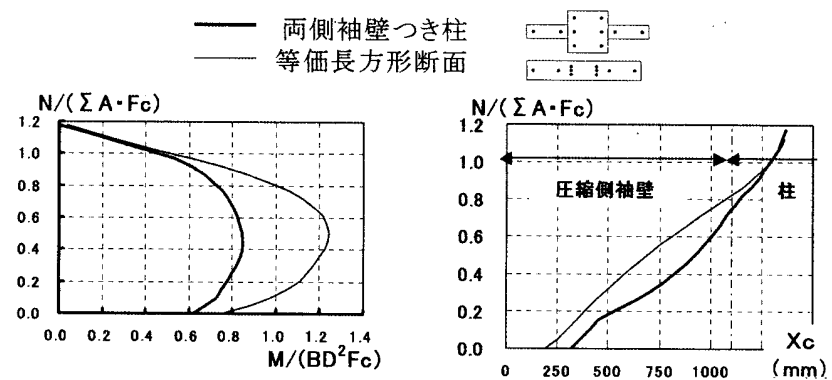

a. $\mathrm{M}-\mathrm{N}$ 相関曲線 b.コンクリート圧縮合力作用位置

図 - 3 両側袖壁付き柱と等価長方形断面の $\mathrm{M}-\mathrm{N}$ 相関曲線 (左) 及びコンクリート圧縮合力作用位置（右）の比較

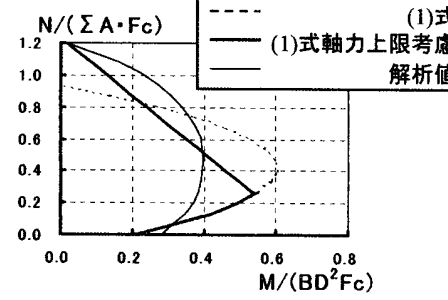

(1) $\mathrm{M}-\mathrm{N}$ 曲線

$(\alpha=0.24, \beta=1.0)$

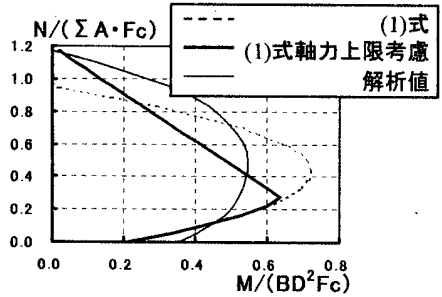

(3) $\mathrm{M}-\mathrm{N}$ 曲線

$(\alpha=0.40, \beta=1.0)$

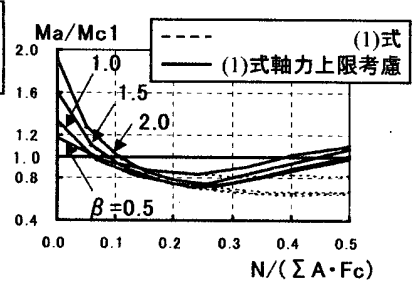

(2)解析値 Ma に対する計算值 Mc1 の比 $(\alpha=0.24)$

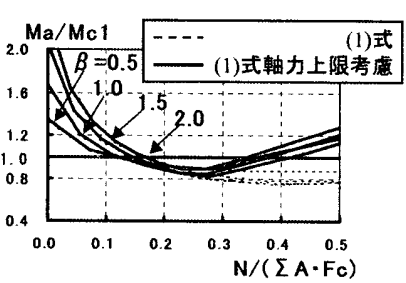

(4)解析値 Ma に対する計算値 Mc1 の比 $(\alpha=0.40)$
図 -4 両側袖壁付き柱の解析値と (1) 式による計算值の比較 左 : M-N 相関曲線 右 : 解析值 Ma に対する計算值 M c 1 の比

\section{4. 各曲げ終局強度式と解析結果の比較}

3 章の結果を基に, 柱, 袖壁付き柱, 壁の各曲げ終局強度式によ る計算值と, e 関数法による解析值（以下解析値と記す）の比較を 行う。開口を有する壁は, 構造計算時や耐震診断時には, その開口 の大きさや位置などにより，開口耐震壁か 2 次壁付き柱・梁にモデ ル化される。袖壁付き柱とみなされた場合には, 袖壁形状によりさ らに柱, 袖壁付き柱, 片側袖壁付き柱にモデル化され，各曲げ終局 強度式を適用することにより曲げ終局耐力が算出されている。しか し現在，これら各曲げ終局強度式を適用するにあたって明確なモデ ル化の基準はなく，袖壁付き柱のモデル化は設計者の判断に任され ているのが現状である。そこで本章では各曲げ終局強度式による計 算値と解析值の適合性を検討する。

\section{4-1. 袖壁付き柱の曲げ終局強度式との比較}

以下に示す袖壁付き柱の曲げ終局強度式 ((1) 式, (3) 式) は, 日本 建築学会の鉄筋コンクリート終局強度設計に関寸る資料 ${ }^{2}$ に記載さ れているものである。このうち(1) 式は，文献1)などに記載され一般 的に用いられている式である。(1) 式，(3) 式は図- 5 に示すような仮 定断面の基で，コンクリート圧縮縁の歪 $\varepsilon$ 、が終局歪に達するのと 同時に, 柱引張主筋が降伏歪 $\varepsilon$, に達したときの断面の曲げモーメ ントを求めることにより算出されている。(1) 式は, コンクリート断 面幅を等価長方形断面の幅 $b_{\mathrm{e}}$ とし, 鉄筋は柱引張り主筋のみを考慮 している。一方 (3) 式はコンクリート断面幅を壁厚 $\mathrm{t}$ とし, 柱・壁の 全ての鉄筋を考慮している。また，文献1）には記載されていないが, 上記の仮定の基で式が導かれているため, 文献 2) においては(2) 式, （4）式のような軸力制限がなされている。(2) 式，(4) 式は，コンクリー 卜圧縮縁が終局歪に達すると同時に柱引張鉄笳が降伏する時の軸力 である。以下に，これら(1)，(3) 式による計算值と両側袖壁付き柱と 圧縮側片側袖壁付き柱の解析值の比較を行う。引張側片側袖壁付き 柱に関しては, 耐震診断では一般的に袖壁が無視されているため, ここでは比較を行わない。

\section{a．両側袖壁付き柱の場合}

図一 4. (1), (3)は, 両側袖壁付き柱の解析值と (1) 式による計算值 を比較したものである。図ー4，(2)，(4)は，横軸に軸力比を，縦軸 に解析值 (Ma) を(1) 式による計算值 (Mc1) で除したものをプロットした ものである。また, 図中の点線は, 軸力上限値を考虑しない場合で あり，太線は（2）式による軸力上限值を考慮し，これを超える軸力 については, 最大圧縮強度と軸力上限值の点を直線で結ぶことによ り表現したものである。図ー4. (2)，(4)に示すとおり，解析值に対

袖壁付き柱の曲げ終局強度式

$$
\begin{gathered}
M_{u}=(0.9+\beta) a_{t} \sigma_{y} D+0.5 N D\left\{1+2 \beta-\frac{N}{b_{e} D F_{c}}\left(1+\frac{a_{t} \sigma_{y}}{N}\right)^{2}\right\} \\
N \leq\left\{0.5 \frac{b_{e}}{B}(0.9+\beta)-13 p_{t}\right\} B D F_{c} \\
\cdots \cdots(1) \text { 试 } \\
M_{u 2}=\left(g_{1}+\beta_{c}\right) a_{t} \sigma_{y} D+\left\{1+0.5\left(\beta_{t}+\beta_{c}\right)\right\} \sum a_{w t} \sigma_{w y} D \\
+0.5 N D\left[1+2 \beta_{c}-\frac{N}{t D F_{c}}\left\{1+(1+\gamma) \frac{a_{t} \sigma_{y}}{N}\right\}^{2}\right] \\
\cdots \\
N \leq\left\{0.5 \frac{t}{B}\left(0.9+\beta_{c}\right)-13 p_{t}(1-\gamma)\right\} B D F_{c}
\end{gathered}
$$

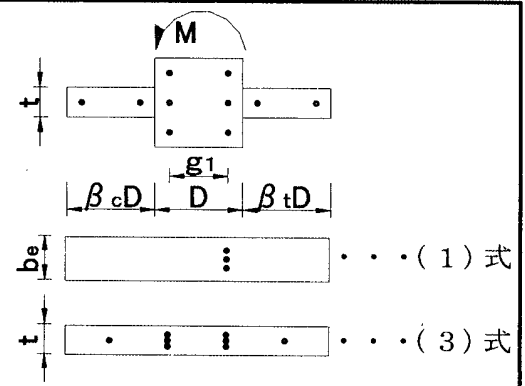

図-5(1) 式, (3) 式 誘導時の袖壁付き柱のモデル化

【記号】 $\alpha$ : 壁厚比, $\beta$ : 張出比, $\mathrm{g}_{1}$ : 柱主筋重心間距離を $\mathrm{D} て ゙$ 除したもの, $\mathrm{a}_{\mathrm{t}}, \sigma_{\mathrm{y}}$ : 柱引張鉄筋断面積 $\left(\mathrm{mm}^{2}\right)$ 及びその 降伏強度 $\left(\mathrm{N} / \mathrm{mm}^{2}\right), \mathrm{a}_{\mathrm{wt}}, \sigma_{w \mathrm{y}}$ : 壁繸筇断面積 $\left(\mathrm{mm}^{2}\right)$ 及びその降伏強度 $\left(\mathrm{N} / \mathrm{mm}^{2}\right), \mathrm{N}$ : 軸力 $(\mathrm{N}), \mathrm{F}_{\mathrm{c}}:$ コンクリート圧縮強度 $(\mathrm{N} /$ $\left.\mathrm{mm}^{2}\right), \mathrm{t}$ : 壁厚 $(\mathrm{mm}), \mathrm{b}_{\mathrm{e}}$ : 等価長方形断面積の幅 $\left(=\mathrm{D} \cdot\left(1+\alpha\left(\beta_{\mathrm{c}}+\beta_{\mathrm{t}}\right) /\left(1+\left(\beta_{\mathrm{c}}+\beta_{\mathrm{t}}\right)\right)\right), \mathrm{p}_{\mathrm{t}}\right.$ : 柱引張主筋鉄筋 比, $\gamma$ : 柱引張主筋応力に対する柱圧縮主筋応力の比 $\left(=\left(1.6-\beta_{\mathrm{e}}\right) /\left(1+\beta_{\mathrm{c}}\right)\right)$ 
する計算值の比は, 軸力比 0.5 までを考えると, 軸力比 $0.1 \sim 0.2$ 付 近を境に，それより低軸力では解析值は計算值より高い值に，高い 軸力では低い值となることがわかる。この傾向は袖壁長さが長くな るほど顕著で，Ma/Mc1 は最大で2.31（ $\alpha=0.4, \beta=2.0 ）$ となる。図一 4 より，(1) 式による計算值は，軸力上限值を考慮するしないにかか わらず，袖壁付き柱の $\mathrm{M}-\mathrm{N}$ 相関曲線を適切に表現できないことがわ かる。

図-6 は，同じく両側袖壁付き柱と（3）式による計算値を比較した ものである。軸力上限を考慮した場合のみを比較してある。（3）式は， コンクリート断面幅を壁厚としているため, 中立軸が圧縮側袖壁に ある低軸力の範囲 $(0 \sim 0.1$ 付近）では, (1) 式よりも計算値に対する 解析值の比 $(\mathrm{Ma} / \mathrm{Mc} 3)$ が小さいが，この場合においても $\beta$ が 0.5 以 上の場合においては，軸力 0 時にはMa/Mc 3 は 1.2 以上となる。また 軸力比 0.1 以上では解析值と計算值の差が大きい。(1) 式と同様に(3) 式も袖壁付き柱のM-N 関係を表現することはできないことがわかる。

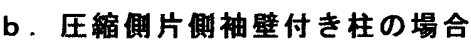

図-7,8 は，a．と同様に，圧縮側片側袖壁付き柱の解析值と (1), (3) 式による計算值の比較を示している。(1) 式の場合，両側袖壁付き 柱と同樣に，やはり低軸力では解析值が計算值より高い值となり， 高軸力の場合はその逆の傾向を示している。(3) 式では，軸力比 0.1 0.3 付近では解析值と計算值は比較的よい対応をしているが，それ以 外の範囲では解析值と計算值の差が大きい。圧縮側片側袖壁付き柱 の場合においても a. と同様, (1)，(3) 式では袖壁付き柱の $M-N$ 相関曲 線を表現できないことが分かる。

以上，a.b.の結果より，(1)，(3)式のような，等価長方形断面に置き 換える方法により導かれた曲げ終局強度式では，袖壁付き柱のM-N 関係を適切に表現できないことがわかる。

\section{4-2. 壁の曲げ終局強度式の比較}

袖壁長さが長くなれば，その力学性状は壁に近くなると考えられ る。また，文献 1 ）などにおいても，壁長さがある程度長くなった 場合においては，壁として扱っている。そこで，壁の曲げ終局強度 式による計算値と解析值を比較した。

式(5)，(6)は，日本建築センターの建築物の構造規定 ${ }^{4)}$ などに記載 されている壁の曲げ終局強度式である。このうち(6) 式は文献 1) で 用いられているいるものである。しかし(6) 式は，式からもわかると おり，曲げモーメントが軸力の一次関数となっているため, 袖壁付 き柱の M-N 関係を表現できない。そのため本項では，(5) 式のみにつ いて計算值と解析値を比較するものとする。なお，(5) 式を適用する ために, 袖壁付き柱を図ー9 に示すような断面にモデル化した。

\section{a . 両僋袖壁付き柱の場合}

図-10 には，両側袖壁付き柱の解析値と（5) 式による計算值の M-N 相関曲線の比較と, 計算值に対する解析值の比 (Ma/Mc5) を示してい る。図-10に示すとおり，(5) 式による N-M 相関曲線は軸力比 0.5 を頂 点とした放物線となり，解析值と計算值は似た曲線を描くものの， (1)，(3) 式同様，袖壁付き柱の M-N 関係を追うことができない。また Ma/Mc 5 についても、袖壁付き柱の曲げ終局強度式と同様に, 低軸力 においては解析值が計算値より高くなる傾向を示している。

\section{b . 圧縮側及び引張㑡片側袖壁付き柱の場合}

図-11，12 には，圧縮側および引張側片側袖壁付き柱の解析值と （5）式による計算値の比較と，計算値に対する解析値の比 (Ma/Ma5) を 示している。解析における圧縮側片側袖壁付き柱の $\mathrm{M}-\mathrm{N}$ 相関曲線は 軸力比 $0.1 \sim 0.2$ 付近で最大モーメントを迎えるため, 袖壁付き柱の 曲げ終局強度式の場合と同様に，軸力比 0.5 までを考えると，低軸

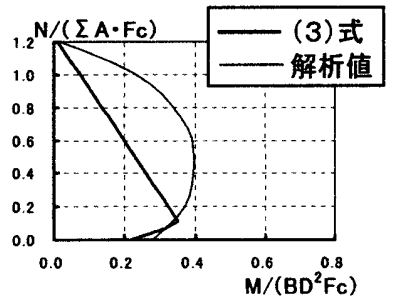

左 : $\mathrm{M}-\mathrm{N}$ 相関曲線

$(\alpha=0.24, \beta=1.0)$

左下：解析值 $\mathrm{Ma}$ に対する

計算值 Mc 3 の比 $(\alpha=0.24)$

右下: 解析値 Ma に対する

計算值 Mc 3 の比 $(\alpha=0.40)$
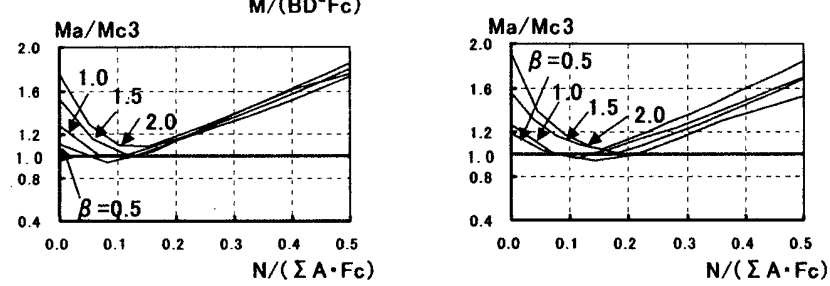

図 - 6 両側袖壁付き柱の解析値と (3) 式による計算值の比較

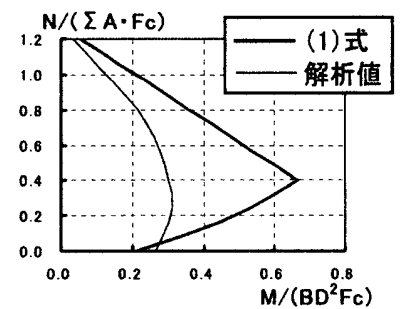

左 : $\mathrm{M}-\mathrm{N}$ 相関曲線

$$
(\alpha=0.24, \beta=1.0)
$$

左下：解析値 $\mathrm{Ma}$ に対する

計算值 $\mathrm{Mc} 1$ の比 $(\alpha=0.24)$

右下：解析值 Ma に対する

計算値 Mc1 の比 $(\alpha=0.40)$
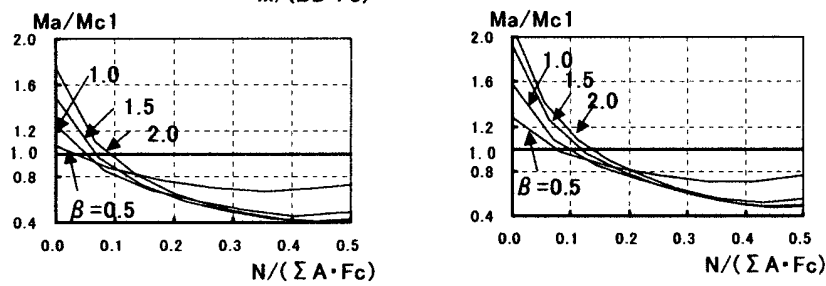

図 - 7 圧縮側袖壁付き柱の解析值と (1) 式による計算值の比較

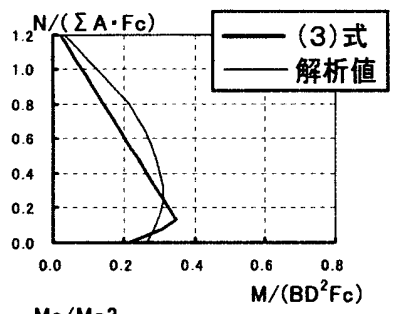

左 $: \mathrm{M}-\mathrm{N}$ 相関曲線

$(\alpha=0.24, \beta=1.0)$

左下：解析値 $\mathrm{Ma}$ に対する

計算値 Mc 3 の比 $(\alpha=0.24)$

右下：解析值 Ma に対する

計算值 Mc 3 の比 $(\alpha=0.40)$
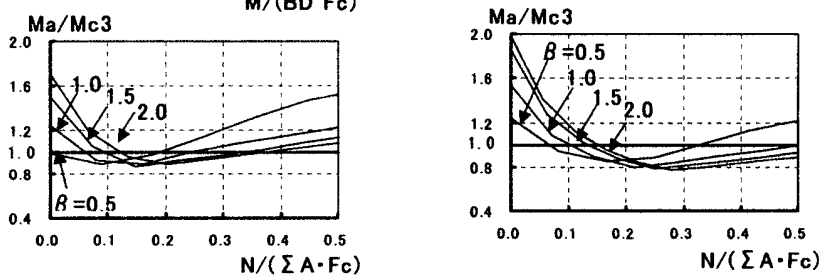

図 - 8 圧縮側袖壁付き柱の解析值と (3) 式による計算値の比較

口壁の曲げ終局強度式

$$
\begin{aligned}
& M_{w}=0.9 a_{\imath} \sigma_{y} D+0.4 a_{w} \sigma_{w y} D+0.5 N D\left(1-\frac{N}{B D F_{c}}\right) \quad \cdots(5) \text { 式 } \\
& M_{w 2}=a_{t} \sigma_{y} l_{w}+0.5 \sum\left(a_{w} \sigma_{w y}\right) l_{w}+0.5 N l_{w} \\
& \cdots(6) \text { 式 }
\end{aligned}
$$

力では解析值は計算值より高い值に，高軸力では低い值となってい る。一方, 引張側片側袖壁付き柱の場合は, 解析で法軸力比 0.5 0.8 付近で曲げモーメントが最大となるために, 比較的計算值は解析

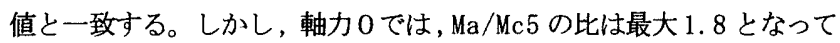
いる。 


\section{(1)両側袖壁付き柱

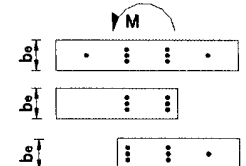

(1) : $\mathrm{a}_{\mathrm{t}} \sigma_{\mathrm{y}}$ に, 壁筋の断面積と降伏強度を， $\mathrm{a}_{\mathrm{w}} \sigma_{w \mathrm{y}}$ に柱主笳の 断面積と降伏強度を代入

(2) : $a_{t} \sigma_{y}$ に, 柱主筋の断面積と降伏強度を, $a_{w} \sigma_{w y}$ は無視

(3) : $a_{t} \sigma_{y}$ k, 壁笳の断面積と降伏強度を, $a_{w} \sigma_{w y}$ に柱主笳の 断面積と降伏強度を代入

なおコンクリートの幅 $\mathrm{B} に は ，$ 等価長方形断面の幅 be を使用する。

図－9 袖壁付き柱を（5）式に適用するにあたっての 断面のモデル化

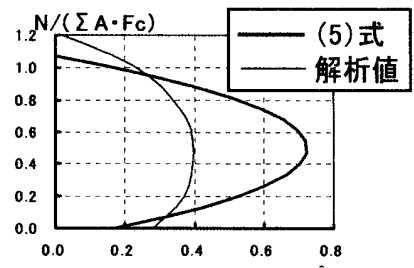

\section{左 $: \mathrm{M}-\mathrm{N}$ 相関曲線 \\ $(\alpha=0.24, \beta=1.0)$}

左下：解析值 M a に対する

計算値 Mc 5 の比（ $\alpha=0.24 ）$ 右下: 解析值 M a に対する

計算值 Mc 5 の比 $(\alpha=0.40)$
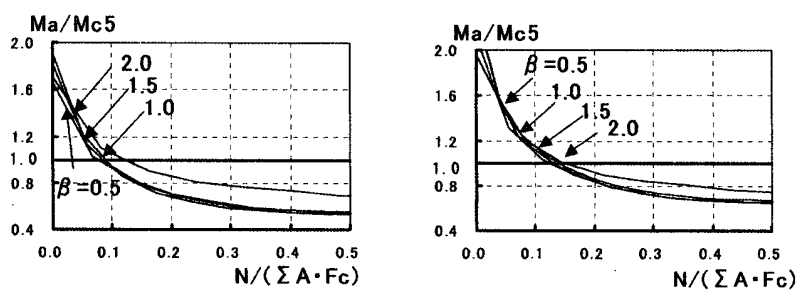

図-10 両側袖壁付き柱の解析值と (5) 式による計算值の比較

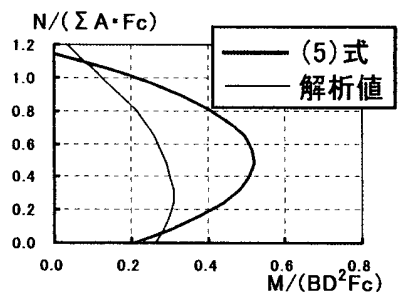

左 $: \mathrm{M}-\mathrm{N}$ 相関曲線

$(\alpha=0.24, \beta=1.0)$

左下：解析值 $M$ a に対する

計算値 Mc 5 の比 $(\alpha=0.24)$

右下：解析値 $\mathrm{Ma}$ に対する

計算値 Mc 5 の比 $(\alpha=0.40)$
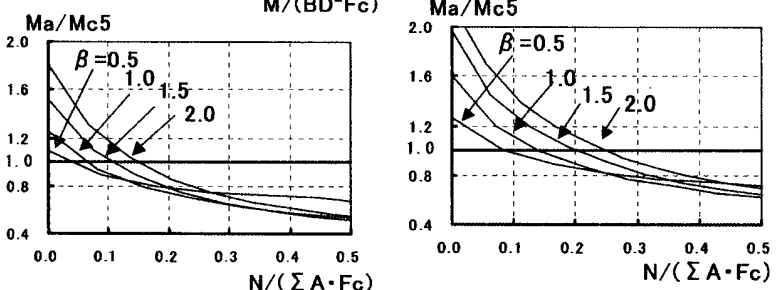

図-11 圧縮側袖壁付き柱の解析值と（5）式による計算值の比較

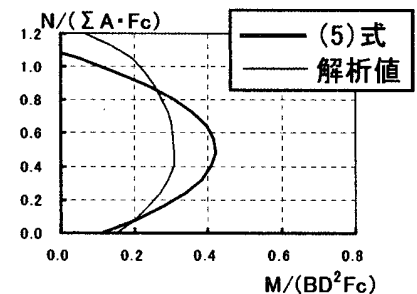

左 $: \mathrm{M}-\mathrm{N}$ 相関曲線

$(\alpha=0.24, \beta=1.0)$

左下：解析值 $\mathrm{Ma}$ に対する

計算值 Mc 5 の比 $(\alpha=0.24)$

右下：解析値 M a に対する

計算値 Mc5 の比（ $\alpha=0.40 ）$
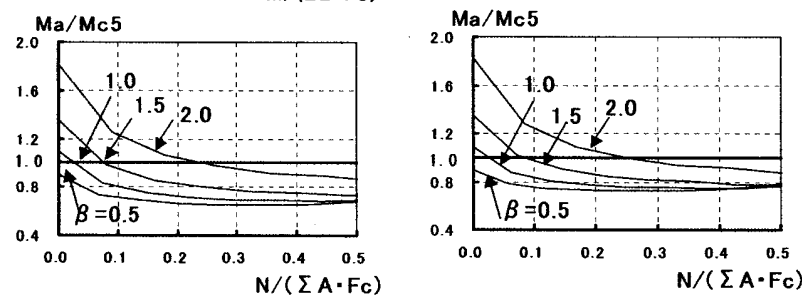

図-12 引張側袖壁付き柱の解析値と（5）式による計算值の比較
口柱の曲げ終局強度式

$$
\begin{array}{lc}
M=0.8 a_{t} \sigma_{y} D+0.5 N D\left(1-\frac{N}{B D F_{c}}\right) & (\mathrm{N} \leqq 0.4 \mathrm{BDFc}) \\
M=\left(0.8 a_{t} \sigma_{y} D+0.12 B D^{2} F_{c}\right)\left(\frac{N_{\text {max }}-N}{N_{\text {max }}-0.4 B D F_{c}}\right) & (\mathrm{N}>0.4 \mathrm{BDFc}) \\
\cdots(7) \text { 式 }
\end{array}
$$

【記号】 $\mathrm{N}_{\max }$ : 圧縮最大軸力 $(\mathrm{N})$, その他の記号は, 袖壁 付き柱の曲げ終局強度式参照。

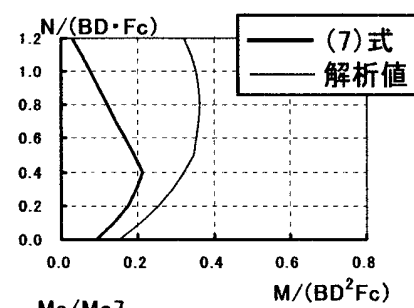

左 $: \mathrm{M}-\mathrm{N}$ 相関曲線

$(\alpha=0.24, \beta=1.0)$

左下：解析値 $\mathrm{Ma}$ に対する

計算値 Mc7 の比 $(\alpha=0.24)$

右下：解析值 Ma に対する

計算值 Mc7 の比 $(\alpha=0.40)$
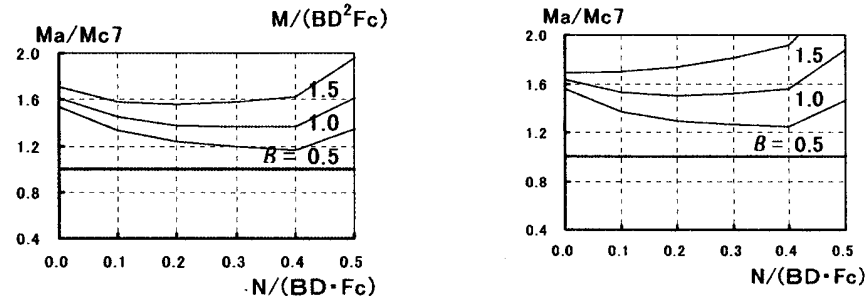

図-13 引張側袖壁付き柱の解析值と（7) 式による計算值の比較

モデル化には検討の余地が有るものの，以上の検討から，壁の曲 げ終局強度式を適用することにより，袖壁付き柱の M-N 関係を表現 することは難しいと思われる。

\section{4 -3．柱の曲げ終局強度式との比較}

引張側片側袖壁付き柱の場合，文献 1）などでは，その壁長さが 短い場合, 袖壁は無視され, 柱の曲げ終局強度式が適用される。し かし，どの程度の袖壁長さまで柱の曲げ終局強度式を適用できるか については記載されていない。そこで，引張側片側袖壁付き柱の解 析值と柱の曲げ終局強度式による計算值を比較した。図-13 には, 引張側片側袖壁付き柱と，柱の曲げ終局強度式 (7) 式による計算值の 比較が示されている。図-13より， $\alpha=0.24, \beta=0.5$ の場合は, 両者 は比較的良い対応を示しているが， $\beta$ が 0.5 であっても， $\alpha$ が 0.4 の 場合は, 計算值に対する解析值の比 $\mathrm{Ma} / \mathrm{Mc} 7$ は, 1.2 を超える。柱の曲 げ終局強度式を適用できるのは，壁厚が薄く，壁長さ $\beta$ が 0.5 程度ま でであることがわかる。

以上の検郡の結果から，文献1）のように，袖壁付き柱に，柱，袖壁 付き柱, 壁の各曲げ終局強度式を適用し，曲げ酎力を正確に算出す るのは，難しいことがわかる。

\section{5、袖壁付き柱の曲げ終局強度式の提案}

4 章の結果, 現行の各曲げ終局強度式を適用し, 袖壁付き柱の曲 げ終局強度を計算するのは難しいことがわかった。そこで新たに袖 壁付き柱の曲げ終局強度式を提案する。袖壁付き柱のような異型断 面に対し，厳密に曲げ終局強度理論を適用し，軸力（中立軸位置） による場合分けを行って曲げ終局強度式を導くことは，式が複雑に なり，使用性に問題がある。本論文では，簡易な形でかつ柱と連続 的に評価できる曲げ終局強度式を提案すること目的とする。

\section{5-1. 両僋袖壁付き柱の曲げ終局強度式の誘導}

日本建築学会の鉄筋コンクリート構造計算基準・同解説（1988） （以下，旧 $\mathrm{RC}$ 基準と記す）の付. 20 梁および柱の曲げ終局強度 ${ }^{5)}$ によ ると, 曲げ終局強度理論を適用して導いた柱の曲げ終局強度式は, 結果的に軸力比とモーメント係数の関係が「つりあい位置以下では 
（中略），その傾向は放物線に近いとされている点をふまえ，柱の 曲げ終局強度略算式を軸力の二次関数として表現している。また， 3 章の袖壁付き柱の曲げ解析結果（図-2, (1), (2)）より, 袖壁付き柱 の M-N 相関曲線はほぼ放物線となっており，また袖壁付き柱と柱の 曲げ終局強度は連続しているはずであるので, 袖壁付き柱について も柱の曲げ終局強度式と同様に, 曲げ終局強度を軸力の二次関数で 表現できると思われる。そこで本研究では，(1)式のように袖壁付き 柱の軸力比とモーメント係数の関係を仮定寸る。ここで, Z は断面倸 数を表す。

この(1)式を柱の曲げ終局強度式 (7) 式と類似な形に展開すると, (2) 式が導かれる。ここでC' は定数項, $\mathrm{v}, \mathrm{w}$ は定数である。 $\alpha, \beta$ が共 に0のとき,つまり袖壁がない場合には, 袖壁付き柱の曲げ終局強 度式は柱の曲げ終局強度式と一致するはずである。そこで, (2)式中 の $\Sigma \mathrm{A}$ に柱の断面積 (=BD) を, Z に柱の断面係数 $\left(=\mathrm{BD}^{2} / 6\right)$ を代入し (7) 式と比較すると, $v=6.0, w=0.5$ を得る。また，(2)式において，定数 項 C' は軸力 0 時の曲げ終局強度であり, 点線内部の係数は $\mathrm{M}-\mathrm{N}$ 相関 曲線を特徴付ける係数である。そこで, 定数 $\mathrm{C}^{\prime}$ を $\mathrm{M}_{0}$, 点線内部の係 数をa とおき，それぞれ以下のように求めた。

\section{( I ) $\|_{0}$ の算出}

$M_{0}$ は, e 関数法による解析結果をふまえ, 図-15に示すような以下 の a ） c ）で仮定される軸力 0 時の両側袖壁付き柱の曲げモーメ ントを計算することで求める。

a）壁縦笳 $\mathrm{a}_{w t}, \mathrm{a}_{w c}$ は壁の中央に集中して存在し，それぞれ終局時 に圧縮, 引張降伏する。

b ）コンクリートの圧縮合力位置 X c は軸力 0 時の曲げ解析結果か ら張出比 $\beta$ の関数として逆算的に求める。

c ）終局時に、柱引張主筋は引張降伏する。柱圧縮主筋は，断面の 軸力の釣り合いを満たすような応力を負担することとする。こ のとき, コンクリート圧縮合力の計算には, b) の結果に対し, ACI 基準による圧縮ブロック形状係数を適用することで算出する。 ここで，圧縮ブロックの幅は，柱内部に中立軸が入った場合は 等価長方形断面の幅 b e とし, それ以外は壁厚 $\mathrm{t}$ とする。

いま，圧縮縁からコンクリートの圧縮合力作用位置までの距離を $\mathrm{X} \mathrm{c}=\mathrm{dc} \cdot \mathrm{D}$ と表すと，図-15 の断面曲げモーメントは，(3)式で表される。 次に, 係数 $\mathrm{dc}$ を求める。図-16に, 曲げ解析から得られた $\mathrm{dc}(=\mathrm{Xc} / \mathrm{D})$ と圧縮側張出比 $\beta_{\mathrm{c}}$ との関係を示す。図-16 には，3 章で求めた解析 結果のほかに，既往の実験にお污る試験体 ${ }^{6}$ ),7)の曲げ解析結果もプ ロットされている。図-16より, dc はほぼ $\beta$ 。卡比例関倸にあること がわかる。そこで, 最小 2 剩法により $\mathrm{dc}$ を $\beta$ 。 の 1 次関数として線形 近似すると，(4)式のようになる。この式を(3)式に代入することによ り、 $M_{0}$ は(8) 式のように表される。また(4)式より，中立軸が柱断面内 部に入る場合の $\beta_{\mathrm{c}}$ を逆算して求めた。この結果 $\beta_{\mathrm{c}}=0.8$ 以下の場合 は中立軸が柱内部に入るため, $\beta_{\mathrm{c}} \leqq 0.8$ の場合，コンクリート幅は be とする。

\section{（II）係数 a の算出}

次に、係数 a を算出する。倸数 $\mathrm{a}$ に，袖壁付き柱の全断面積 $\Sigma \mathrm{A}$ と断面係数 Z（77式）を代入すると，係数 a は8)式のとおりになる。 この8)式を(2)式に代入し，解析值と(2)式による計算值を比較したも のを図-17 に示す。図より，8式では，袖壁付き柱のM-N 関係を追え ないことがわかる。これは 3 章で述べたとおり，袖壁付き柱の $M-N$ 相関曲線は, 壁厚と柱幅の差により, 同じ軸力比であってもコンク リート圧縮合力作用位置が等価長方形断面より柱寄りになることに より（図－3）等価長方形断面とは異なる曲線となるのに対し，8

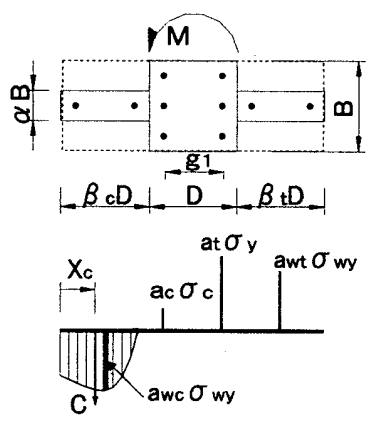

$\mathrm{C}:$ コンクリート合力 $(\mathrm{kN})$

$\mathrm{Xc} ：$ 圧樎緣からコンクリート合力作用 位置までの距離 $(\mathrm{mm})$

$a_{c}$ : 柱圧縮主筋断面積 $\left(\mathrm{mm}^{2}\right)$

$\mathrm{a}_{1}$ : 柱引張主筋断面積 $\left(\mathrm{mm}^{2}\right)$ (柱主筋が多段配箭の場合は， $a_{c}, a_{t}=a_{s} / 2, a_{s}$ : 柱全主筋断面䅡 $)$ $\sigma_{y}$ : 柱引張主筋降伏强度 $\left(\mathrm{N} / \mathrm{mm}^{2}\right)$ $\sigma_{\mathrm{c}}$ : 柱圧縮主筋応力強度 $\left(\mathrm{N} / \mathrm{mm}^{2}\right)$ $\sigma_{\text {, }}$ : 壁笳降伏强度 $\left(\mathrm{N} / \mathrm{mm}^{2}\right)$

$\mathrm{g}:$ 柱主筋重心閒距離 $(\mathrm{mm})$ (柱主筋が多段配筋の場合は, 圧縮側主管之引張側主筋の重心 間距離)

図ー15 M。を算出するため仮定断面
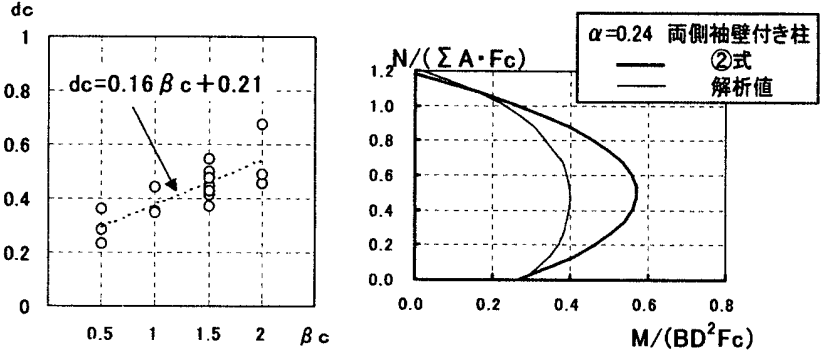

図-16 $\mathrm{dc}$ と $\beta \mathrm{c}$ の関係 図-17 (2)式に(8)式を用いた時の $\mathrm{M}-\mathrm{N}$ 曲線

$$
\begin{aligned}
& \frac{M}{Z F_{c}}=v\left(w-\frac{N}{\sum A * F_{c}}\right)^{2} \\
& M=C^{\prime} \sum_{i} \frac{Z}{\sum A * D^{\prime}} N D\left(2 w-\frac{N}{\sum A * F_{c}}\right) \\
& M_{0}=C\left(0.1+\beta_{c}-d_{c}\right) D+g_{1} a_{1} \sigma_{y} D+\left[1+0.5\left(\beta_{c}+\beta_{t}\right)\right] a_{w t} \sigma_{w y} D \\
& d_{c}=0.16 \beta_{c}+0.21 \\
& C=\frac{k_{1} k_{3}}{k_{2}} d_{c} b^{\prime} F_{c} D=1.7 d_{c} b^{\prime} F_{c} D
\end{aligned}
$$

軸力 0 時の袖壁付き柱の曲げ終局強度

$M_{0}=1.7 F_{c} b^{\prime}\left(0.16 \beta_{c}+0.21\right)\left(0.84 \beta_{c}-0.11\right) D^{2}$

$$
+g a_{t} \sigma_{y} D+\left[1+0.5\left(\beta_{t}+\beta_{c}\right)\right] a_{w t} \sigma_{w y} D
$$

ただし $, b^{\prime}=b e\left(\beta_{\mathrm{c}} \leqq 0.8\right), b^{\prime}=t\left(\beta_{\mathrm{c}}>0.8\right) \quad \cdots(8)$ 式 $a=v \frac{Z}{\sum A * D}$

$Z=\frac{B D^{2}}{6}\left(1+2 \alpha \beta^{3}+6 \alpha \beta(1+\beta)^{2}\right)$

$a_{1}=v \frac{Z}{\sum A * D}=v \frac{1+2 \alpha \beta^{3}+6 \alpha \beta(1+\beta)^{2}}{(2 \alpha \beta+1)(2 \beta+1)}$

$a_{2}=v \frac{Z}{\sum A * D}: \frac{\sum A}{(1+2 \beta) B D}=v \frac{1+2 \alpha \beta^{3}+6 \alpha \beta(1+\beta)^{2}}{(2 \beta+1)^{2}}$

口袖壁付き柱の曲げ終局強度 提案式（両側袖壁付き柱）

$M=M_{0}+a N D\left(1-\frac{N}{\sum A * F_{c}}\right)$ - ・ (9) 式

$a=0.5\left(\frac{1+2 \alpha \beta^{3}+6 \alpha \beta(1+\beta)^{2}}{(1+2 \beta)^{2}}\right)$ $\cdots\left(\begin{array}{ll}1 & 0\end{array}\right)$ 式 

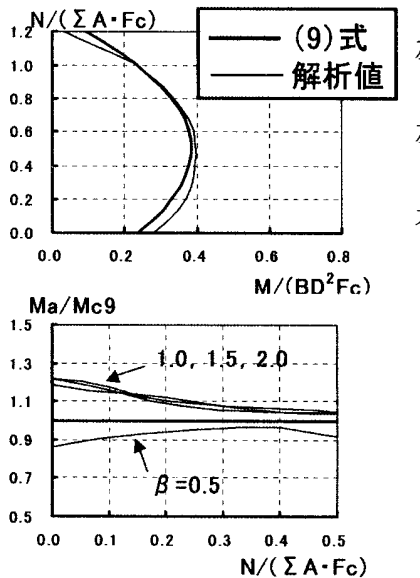

図-18 両側袖壁付き柱の解析値と（9）式による計算値の比較

式の断面係数 Z のみではこれを表現することができないためである と考えられる。そこでさらに，(8)式に(9)式の点線内部の倸数をかけ る。これは，図-15 に示すとおり， $\Sigma \mathrm{A}$ に対する点線内部の面積の比 であり，断面中央部（柱）へのコンクリートの集中率を示し，壁厚と 柱幅の差を表す一つの指標であると考えられる。(9)式を(2)式に代入 して，解析值と(2)式による計算值を比較したものを図一18に示す。図 より，この係数を適用した場合，解析值と計算值は良い対応を示し た。したがって，係数 aに(9)式を用いた（9）式により，両側袖壁付き 柱の M-N 相関曲線は適切に表現できると思われる。

\section{5-2．片溉袖壁付き柱の曲げ終局強度式の誘導}

次に片側袖壁付き柱の曲げ終局強度式を導く。図-19には, 図-15 と同様に, 軸力 0 時の引張側, 及び压縮側片側袖壁付き柱のコンク リート圧縮合力作用位置Xcに対する柱幅 D の比 $\mathrm{dc}(=\mathrm{Xc} / \mathrm{D})$ を示し たものである。引張側片側袖壁付き柱については，dc は壁形状によ らずほぼ同じ值を取り，柱圧縮鉄筋位置 $(d c \fallingdotseq 0.1)$ と等しい。そ こで引張側片側袖壁付き柱に関しては，(8) 式の第一項を無視し，係 数 a には片側袖壁付き柱の断面係数 Z を用いた(11) 式を使用する。ま た，圧縮側片側袖壁付き柱に関しては，d c は両側袖壁付き柱とほぼ 等しいため, $\mathrm{dc}$ は両側袖壁付き柱と同様の式を用いることとし、係 数 $\mathrm{a}$ に関しては，式（12）を用いることとする。

また，圧縮側に袖壁がつく場合，そのM-N 相関曲線は低軸力で最大 モ一メントを迎えるため，(9) 式を適用するにあたって軸力制限を考 える。圧縮側袖壁付き柱の M-N 相関曲線は, 柱引張主筋に対するつ りあい軸力時に曲げモーメントが最大となる。そこで図－20に示す ような仮定断面を考え，この断面のつりあい軸力を計算することに より $\mathrm{N}_{\mathrm{b}}$ を求めた。図一20に示される仮定断面において，断面の歪分 布は平面を保持すると仮定し，

a) 柱引張主筋は降伏歪 $\varepsilon_{y}$ に, コンクリート圧縮縁は終局歪 $\varepsilon_{u}$ に達している。

b ）壁筋は袖壁中央に集中し、圧縮降伏している。

c ）柱引張鉄筋は引張降伏し、圧縮鉄笳は歪分布に応じた応力を負 担する。

$$
\begin{aligned}
& a=0.5\left(\frac{(\alpha \beta+1)\left(\alpha \beta^{3}+1\right)+3 \alpha \beta(1+\beta)^{2}}{(1+\beta)\left(\alpha \beta^{2}+2 \alpha \beta+1\right)}\right) \\
& \quad \text { 引張側袖壁付き柱) } \cdots(11) \text { 式 } \\
& a=0.5\left(\frac{(\alpha \beta+1)\left(\alpha \beta^{3}+1\right)+3 \alpha \beta(1+\beta)^{2}}{(1+\beta)\left(\alpha \beta^{2}+2 \beta+1\right)}\right)
\end{aligned}
$$

(圧縮側袖壁付き柱) …(12) 式

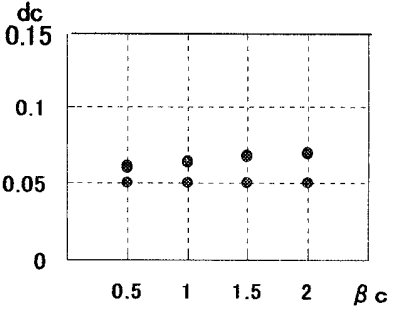

(1)引張側袖壁付き柱

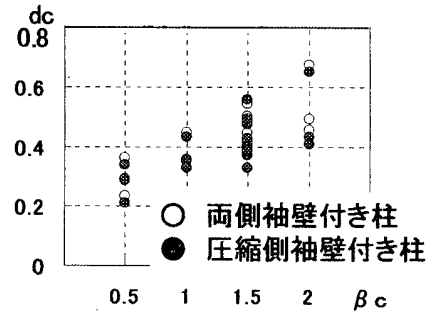

(2)圧縮側袖壁付き柱
図-19 圧縮及び引張側袖壁付き柱の コンクリート圧縮合力作用位置

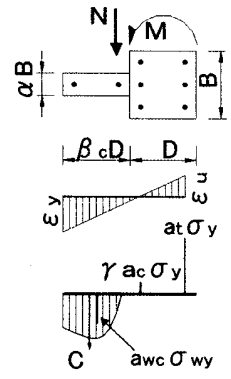

$\varepsilon_{\mathrm{y}}$ : 鉄筋の降伏時歪

$\varepsilon_{u}:$ :コンリートの終局時歪 $\mathrm{a}_{\mathrm{t}}$ : 柱引張主筋の断面積 $\left(\mathrm{m} \mathrm{m}^{2}\right)$

$y:$ 柱の圧縮主筋応力の

引張鉄筋応力に対する比

$\sigma_{\mathrm{y}}$ : 柱主筋降伏強度

$\left(\mathrm{N} / \mathrm{mm}^{2}\right)$

図-20 軸力上限值の算出のための仮定断面

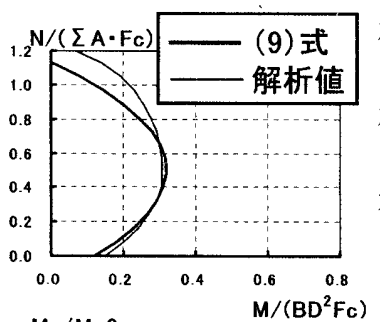

左 $: \mathrm{M}-\mathrm{N}$ 相関曲線

左下：解析值 $\mathrm{a}$ に対寸る

計算值 Mc9 の比 $(\alpha=0.24)$

右下：解析值 $\mathrm{Ma}$ に対寸る

計算值 Mc9 の比（ $\alpha=0.40 ）$
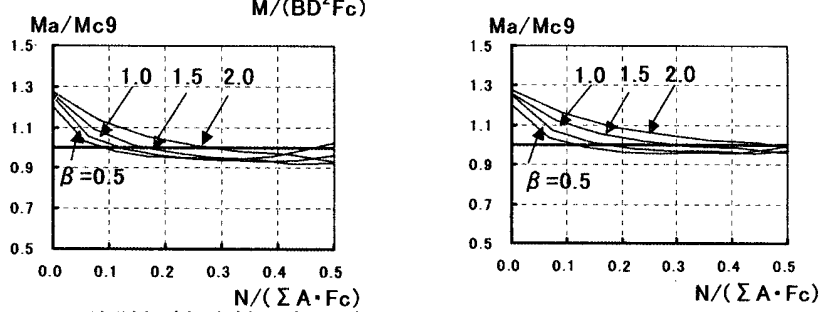

図-21引張側袖壁付き柱の解析値と（9）式による計算值の比較

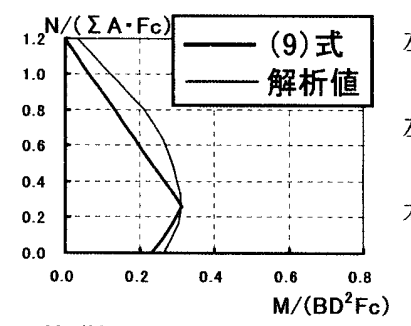

左 : $\mathrm{M}-\mathrm{N}$ 相関曲線

$(\alpha=0.24, \beta=1.0)$

左下: 解析值 $\mathrm{M}$ a に対する

計算值 Mc9 の比 $(\alpha=0.24)$

右下：解析値 $\mathrm{Ma}$ に対する

計算值 Mc9 の比 $(\alpha=0.40)$
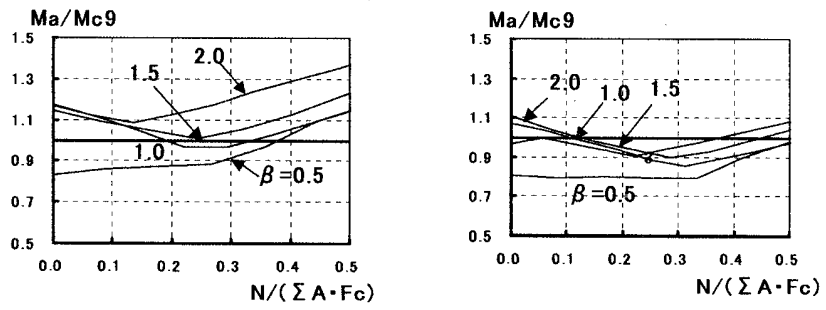

図-22 圧縮側袖壁付き柱の解析值と（9) 式による計算值の比較

(9) 式の軸力上限值（圧縮袖壁付き柱のみ）

$N_{b}=0.45 b^{\prime}(\beta+0.9) D F_{c}-(1-\gamma) a_{t} \sigma_{y}+a_{w t} o_{w y} \quad \cdots \cdot(13)$ 式

ただし、 $\gamma=\frac{2.6 g}{0.9+\beta}-1$

$b^{\prime}=b e \quad(\beta c \leqq 1.4), b^{\prime}=t \quad(\beta c>1.4) \quad \cdots(15)$ 式 
d）コンクリートの圧縮ブロックにはACI 基準による圧縮ブロック 形状係数を使用し，コンクリートの幅は，中立軸が柱内部にあ る場合は等価断面の幅 be を, 袖壁内にある場合は袖壁厚さ $\mathrm{t}$ と する。

主筋の降伏歪 $\varepsilon$, に対するコンクリート圧縮終局歪 $\varepsilon$ u $の$ 比はほぼ 1.6 であると考え，図-20 に仮定した断面の軸力 $\mathrm{N}_{\mathrm{b}}$ を求めると (13) 式 となる。 $\mathrm{b}^{\prime}$ はd)の仮定により，(15) 式のように $\beta_{\mathrm{c}}$ により場合分けさ れる。

(9) 式と引張側及び圧縮側片側袖壁付き柱の M-N 相関曲線を比較し たものが，図-21，22である。図-21，図-22より，（9）式は片側袖 壁付き柱の解析値に対しても良い対応を示した。

以上の結果より,(9)式は， $\alpha ， \beta$, 壁取り付き位置によらず, 袖壁 付き柱の $M-\mathrm{N}$ 相関曲線を適切に表現できると思われる。

\section{5-3. 既往の実験値と提案式の比較}

最後に，(9) 式の信頼性を検討するために, 既往の袖壁付き柱, 腰 壁たれ壁付き梁の実験結果 ${ }^{6}$ ，7),8) と(9) 式による計算值の比較を行っ た。参考にした試験体は，既往の 2 次壁付き柱・梁の実験において 曲げ破壊した試験体 19 体である（両側袖壁付き柱 4 体，たれ壁腰壁 つき梁 13 体，片側袖壁付き柱 1 体)。袖壁付き柱の全断面に対する軸 力比は $0.09 \sim 0.14, \alpha$ は $0.24 \sim 0.32, \beta$ は $0.5 \sim 2.0$, コンクリート 強度 $14.8 \sim 19.9\left(\mathrm{~N} / \mathrm{mm}^{2}\right)$, 柱 (梁) 主笳比 $0.68 \sim 0.77(\%)$, 柱主筋降 伏強度 $\left.326 \sim 401 （ \mathrm{~N} / \mathrm{mm}^{2}\right)$ ，壁繸筋比 $0.31 \sim 0.37(\%)$ ，壁繸筋降伏強度 $223 \sim 362\left(\mathrm{~N} / \mathrm{mm}^{2}\right)$ である。既往の実験においては, 袖壁とともに腰 壁たれ壁も付加する試験体があるが，この場合，ヒンジ位置が問題 となるため，検討から省いた。

図-23 の縋軸は実験から得られた曲げ終局時のせん断力 Qexp $(\mathrm{kN})$ 横軸は袖壁付き柱の曲げ終局強度式 (1) 式および5章において提案し た(9) 式により求められた曲げ終局強度時のせん断力Qcal (kN) であ る。図 -23, (1)より, 軸力が 0 の試験体では, Qexp/Qcal の平均値は (1) 式で $0.74 ，(9)$ 式で 1.01 , 標準偏差は(1) 式で $0.05 ，(9)$ 式で 0.10 となり，（9）式は(1) 式より実験値と良い詨応を示している。また 図-23，(2)より，軸力がある試験体については, Qexp/Qca1 の平均值は (1) 式で $0.94, （ 9)$ 式で 0.89 , 標準偏差は(1) 式で 0.07, （9）式は 0.09 となり，（1）式，（9）式ともに実験結果と良い対応を示して いる。これは，これらの実験の軸力比が $0.09 \sim 0.14$ と低軸力であり 図-24に示すとおり，(1) 式による計算值と解析值がほぼ一致する軸 力範囲であったためである。片側袖壁付き柱については, 試験体数 が 1 体と少ないが，(9) 式による計算值と実験值は良い対応を示して いる。

以上の結果から,(9) 式は, 袖壁付き柱の曲げ終局強度を, 袖壁厚, 袖壁長, 壁取りつき位置によらず, 適切に求めれられるものと思わ れる。

\section{6. まとめ}

本研究では，柱の曲げ耐力に及ぼす袖壁長さ，厚さ，取り付き位 置の影響を $\mathrm{e}$ 関数法を用いた曲け解析により検討した。その結果, 以下の知見を得た。

(1)袖壁付き柱の曲げモーメントー 軸力相関曲線は, 柱のような長 方形断面とは異なった挙動を示す。これは主に壁厚と柱幅の差から 生じるものである。

(2)解析結果と, 現行の柱, 袖壁付き柱, 壁の各曲げ終局強度式を 比較検討した結果, いずれの式も，袖壁付き柱の曲げモーメントー 軸力関倸を適切に表現できないことを示した。
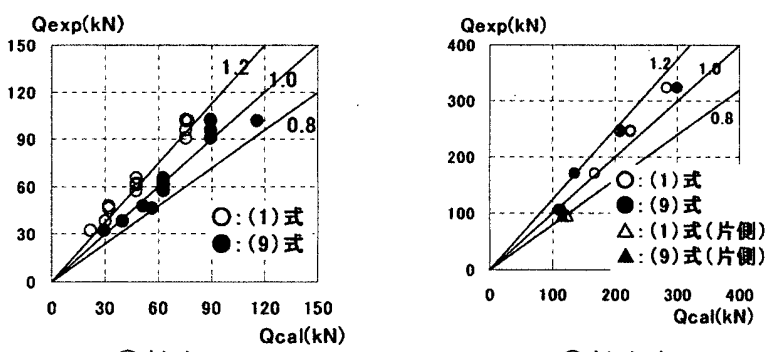

(2)軸力有り

$(\mathrm{N} /(\Sigma \mathrm{AFc})=0.09 \sim 0.14)$

図-23（1）式、（9）式による計算值と実験值の比較
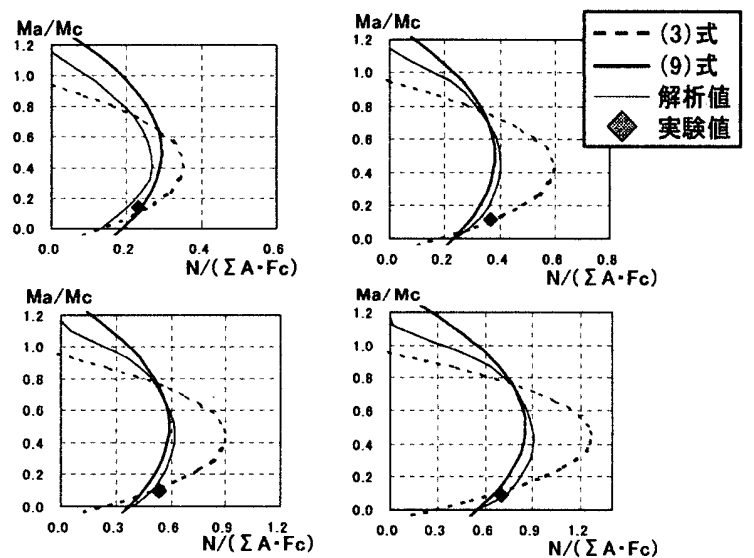

図-24（1）式、(9) 式による計算値と実験值・解析値の比較 （両側袖壁付き柱・軸力があるもの 4 体）

(3) $\mathrm{e}$ 関数法による曲げ解析結果を基に，新たに簡易な形で，かつ 柱と連続的に評価できる曲げ終局強度式を提案した。提案式は，壁 厚比 $\alpha$ が $0.24 \sim 0.40$, 張出比 $\beta$ が $0.5 \sim 2.0$ の範囲において, 袖壁長 袖壁厚, 壁取り付き位置によらず, 解析值, 既往の実験値の両者と良 い対応を示した。

ただし，e 関数法による曲げ解析では，軸力は全断面の塑性重心 位置に作用するものとしたため，袖壁が建物内に単層で存在し，か つその袖壁長さが梁・柱に比べて十分長い場合については, 軸力作 用位置が異なることが考えられる。この場合，本提案式は適用外で あり，別途曲げ終局強度の検討が必要であると思われる。

\section{参考文献}

1）日本建築防災協会：既存鉄筋コンクリート造建築物の耐震診断基海 · 同解説、 1990

2) 日本建筑学会：鉄筋コンクリート終局強度設計に関する資料， pp. $59-61,1987$

3）文部省 : 学校施設の耐震補強マニュアル RC 造校舎編, 1998

4）日本建築センター : 建築物の構造規定, 1998

5) 日本建築学会 : 鉄筋コンクリート構造計算基準・同解説, pp. $604 \sim 619,1988$

6）東洋一、大久保全陸、飯田研：腰壁，たれ壁付き鉄筋コンクリート梁の 弹塑性挙動に関する実験的研究（その 1 . 実嗱概要および曲げ破境性状） 日本建築学会構造系論文集，第 204 号, pp. 1-7, 1973.2

7 ）東洋一，大久保全陸：鉄筋コンクリート短柱の崩壊防止に関する総合 研究（その 9), 日本建笨学会大会学郝講演梗概集, 構造系, pp 1305-1306、1974

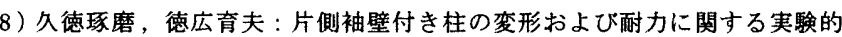
研究, 日本建筑学会大会学術講演梗概集, C 構造系 II , pp. 773-774, 1988. 10

9）大宫幸, 香取慶一, 林静雄 : R C 造柱の耐力に及ぼす袖壁長及び袖壁厚 の影響に関する解析、コンクリート工学年次論文報告集, Vol. 21 No. 3, pp. 1351-1356, 1999. 7

10 ）郭済荅、大宮幸、香取慶一、林静雄： R C 造柱の曲外とせん断耐力に 及ぼす袖壁の影響（その1 曲げ耐力に及ぼす影響），

日本建築学会大会学術講演梗概集、C 構造 II , pp. 829-830、1999.9

(2000年 6 月 10 日原稿受理，2000年11月27日採用決定) 